\title{
Pollen morphology of the Central European broomrapes (Orobanchaceae: Orobanche, Phelipanche and Orobanchella) and its taxonomical implications
}

\author{
Renata Piwowarczyk $\cdot$ Jacek Madeja • \\ Marcin Nobis
}

Received: 17 April 2014/ Accepted: 27 June 2014/Published online: 29 July 2014

(C) The Author(s) 2014. This article is published with open access at Springerlink.com

\begin{abstract}
Pollen grains of 450 samples of 25 species of the genus Orobanche and Phelipanche occurring in Central Europe were investigated using light and scanning electron microscopy. Palynological data on 18 species are reported here for the first time. The usefulness of micromorphological studies on pollen of Orobanche and Phelipanche is demonstrated. Previous research showed the separation of Phelipanche from Orobanche, a finding which is also supported by pollen aperture type and exine ornamentation. The pollen of Phelipanche is tricolpate, while that of Orobanche is inaperturate. Our research showed that one of the species included so far within Orobanche, namely $O$. coerulescens, has tricolpate pollen with microreticulate sculpture. As a consequence of the finding of tricolpate pollen and intermediate macromorphological characteristics of this species between Orobanche and Phelipanche, it is proposed to transfer it to a new genus, Orobanchella, described in the paper. A comparison of the main characteristics distinguishing Orobanche, Phelipanche, Boulardia and Orobanchella is also presented and discussed.
\end{abstract}

R. Piwowarczyk ( $\square)$

Department of Botany, Institute of Biology, Jan Kochanowski

University, 15 Świętokrzyska St., 25-406 Kielce, Poland

e-mail: renka76@wp.pl; renata.piwowarczyk@ujk.edu.pl

J. Madeja

Department of Palaeobotany and Palaeoherbarium, Institute of Botany, Jagiellonian University, 46 Lubicz St., 31-512 Kraków, Poland

e-mail: jacek.madeja@uj.edu.pl

M. Nobis

Department of Plant Taxonomy, Phytogeography and

Herbarium, Institute of Botany, Jagiellonian University,

Kopernika 27 St., 31-501 Kraków, Poland

e-mail: m.nobis@uj.edu.pl
Keywords Orobanche Phelipanche - Orobanchella . Pollen · Morphology $\cdot$ Systematic significance $\cdot$ SEM

\section{Introduction}

The family Orobanchaceae contains 15 obligate parasitic genera with ca 250 species (Pusch and Günther 2009). The family has a worldwide distribution, but the main centres of distribution are the Mediterranean, western and central Asia, northern Africa and North America (Kreutz 1995). Orobanche s.l. is the largest genus and comprises more than 200 species, which lack chlorophyll and are holoparasites of the roots of other vascular plants (Uhlich et al. 1995; Pusch and Günther 2009). In Europe, these species usually grow in the warmest regions, with the highest species diversity in the Mediterranean countries. In central and northern parts of Europe the genus comprises about 30 species, which are mostly rare, endangered or declining (e.g. Zázvorka 1997, 2000; Pusch and Günther 2009; Halamski and Piwowarczyk 2008; Piwowarczyk and Przemyski 2009, 2010; Piwowarczyk et al. 2009, 2010, 2011; Piwowarczyk 2011, 2012a, b, c, d, e, f, g, h, 2013; Nobis et al. 2014).

The genus Orobanche has traditionally been divided into four sections: Trionychon, Orobanche, Gymnocaulis and Myzorrhiza (Beck von Mannagetta 1930). In the most recent taxonomic treatments, these sections have been recognised as separate genera: Aphyllon, Myzorrhiza, Phelipanche, Boulardia and Orobanche. However, the classification of Phelipanche (syn. O. sect. Trionychon) and Boulardia (syn. Orobanche latisquama) as separate genera is still being discussed (Holub 1977, 1990; Teryokhin et al. 1993; Schneeweiss 2001; Manen et al. 2004; Schneeweiss et al. 2004a, b; Weiss-Schneeweiss et al. 
2006; Bennett and Mathews 2006; Schneeweiss 2007; Park et al. 2007a, b; Pujadas Salvà 2007; Carlón et al. 2008). Some authors still treat the genus Orobanche s.l. in a wide sense (Greuter and Raab-Straube 2009). The separation of Phelipanche and Orobanche is confirmed by recent molecular phylogenetic studies (e.g. Schneeweiss et al. 2004a, b; Manen et al. 2004; Park et al. 2007a, b); morphological and carpological differences (Holub 1977; Teryokhin 1997; Joel 2009a, b); chemotaxonomic study (Velasco et al. 2000) and micromorphology of seeds (e.g. Abu Sbaih and Jury 1994; Plaza et al. 2004); and pollen grains (Zare et al. 2013). According to the authors of a recent study (Zare et al. 2013), verrucate exine ornamentation and inaperturate pollen type suggest a close relationship between Orobanche, Boulardia and Diphelypaea, whereas tricolpate pollen suggests a relationship between Cistanche and Phelipanche.

The flowers in Orobanche are always bisexual, with superior ovaries, more or less zygomorphic, with four didynamous stamens and two or three lobed stigma, characterised by cross-pollination or, rarely, by the absence of insects, i.e. self-pollination (Beck von Mannagetta 1930; Teryokhin 1997; Jones 1991). There are many adaptations of flowers for pollination: large or small flowers gathered in dense inflorescences; contrasting colouration and shine of the corolla and stigma; a wide range of often bright colours; the smell of the flowers, either pleasant (scent of cloves, e.g. O. alba, O. caryophyllacea, O. crenata, O. gracilis) or unpleasant (the smell of carrion, e.g. O. foetida, $O$. rigens, $O$. rapum-genistae, $O$. variegata) (the majority of species have a weak scent or none); the lower lip of the corolla serving as an alighting place for pollinators (two bright folds, coated with hairs); the production of nectar from coloured spots. Most species are pollinated by bumblebees and bees (Apidae), as well as, albeit less importantly, by species of the families Syrphidae, Vespidae, or Formicidae or carrion flies (Diptera) (Piwowarczyk, unpublished). Preliminary studies in relation to pollination and other shared interactions between parasitic plants and their hosts are presented by Ollerton et al. (2007).

Orobanchaceae is a eurypalynous family, with different types of pollen. Nevertheless, in many cases the biometric and morphological features of pollen grains possess a high diagnostic significance and are used in taxonomy. Pollen taxonomy can also explain the relationship and phylogenetic connections between particular genera of the family. Exine sculpture is one of the most important features and is a good tool in the recognition of genera or sections within a genus. Unfortunately, there are still not many papers dedicated to the pollen morphology of the family Orobanchaceae (e.g. Tiagi 1951; Rao 1963; Erdtman 1966; Polo 1987; Minkin and Eshbaugh 1989; Abu Sbaih et al. 1994; Teryokhin 1997; Shahi Shavvon and Saeidi Mehrvarz
2010; Zare and Dönmez 2013; Zare et al. 2013; Piwowarczyk et al. 2014) and further studies within the whole family are required.

The aim of the study was to present (1) the macro- and micromorphological variability of pollen in the Central European Orobanche and Phelipanche taxa; (2) the taxonomic implications of pollen morphology in the examined taxa.

\section{Materials and methods}

Plant material

This study is based on plant material deposited mainly in the KTC herbarium. In total, 25 taxa of three genera, Orobanche, Phelipanche and Orobanchella, were analysed. A list of voucher specimens used in the study is given in Table 1. Each sample corresponds to a single plant, but pollen grains originating from different flowers have not been distinguished.

\section{Light microscopy observations}

The pollen grains were prepared with the standard method, Erdtman's acetolysis (Erdtman 1969; Faegri and Iversen 1989). Following acetolysis, the pollen grains were mounted in glycerine jelly and prepared for LM observation. Some characteristics, such as polar and equatorial axis and exine thickness, were examined by LM (Axio Imager 2 , Zeiss) for 30 pollen grains under $1,000 \times$ magnifications with the help of the AxioVision computer program (version 4.8.1.0, Carl Zeiss Imaging Solutions). Measurements were taken under the light microscope only in accordance with changes in pollen shape and dimensions occurring during its preparation for SEM.

\section{Scanning electron microscopy (SEM) observation}

Using SEM observation, we analysed 450 samples of 25 taxa. For SEM observation, samples were coated with gold using a JFC-1100E Ion Sputter manufactured by JEOL. Micromorphological structures of pollen grains were observed and photographs taken by means of Hitachi S-4700 and Philips XL 20 scanning electron microscopes at various magnifications. The terminology was adopted from Punt et al. (2007) and Hesse et al. (2009).

Morphometric analysis

The statistical analyses are based on 1,170 fully-developed pollen grains from 25 taxa. Characteristics were measured in 30 grains of each specimen studied (Table 1). Finally, a 
Table 1 Taxa used in this study and voucher information

\begin{tabular}{|c|c|c|c|c|}
\hline Number & Taxon & Locality & Voucher & Host \\
\hline & Orobanche & & & \\
\hline 1 & O. alba subsp. alba & Poland & Bieszczady Mts, 14 Aug 2009, R. Piwowarczyk (KTC) & Thymus pulegioides \\
\hline $2 \mathrm{a}$ & O. alba subsp. major & Poland & Lasocin, 27 Jul 2006, R. Piwowarczyk (KTC) & Salvia verticillata \\
\hline $2 b$ & O. alba subsp. major & & Kąty II, 15 Jul 2006, R. Piwowarczyk (KTC) & Salvia verticillata \\
\hline 3 & O. alsatica & Poland & Broczówka, 8 Jun 2007, R. Piwowarczyk (KTC) & Peucedanum cervaria \\
\hline 4 & O. bartlingii & Poland & Podzamcze, 4 Jun 2009, R. Piwowarczyk (KTC) & Libanotis pyrenaica \\
\hline $5 \mathrm{a}$ & O. caryophyllacea & Poland & Teresin, 8 Jun 2007, R. Piwowarczyk (KTC) & Galium mollugo \\
\hline $5 \mathrm{~b}$ & O. caryophyllacea & & Bogucice, 6 Jun 2007, R. Piwowarczyk (KTC) & Galium odoratum \\
\hline $5 \mathrm{c}$ & O. caryophyllacea & & Pieniny Mts, Kozia Mt, 23 Jul 2010, R. Piwowarczyk (KTC) & Galium mollugo \\
\hline 6 & O. crenata & Spain & Cordoba, 2 May 2012, R. Piwowarczyk (KTC) & Vicia sp. \\
\hline $7 \mathrm{a}$ & O. elatior & Poland & Baldram, 07 Jul 2010, R. Piwowarczyk (KTC) & Centaurea scabiosa \\
\hline $7 b$ & O. elatior & & Wólka Leszczańska, 08 Jun 2008, R. Piwowarczyk (KTC) & Centaurea scabiosa \\
\hline $8 \mathrm{a}$ & O. flava & Poland & Tatra Mts, Mała Łąka Valley, 22 Jun 2009, R. Piwowarczyk (KTC) & Petasites kablikianus \\
\hline $8 \mathrm{~b}$ & O. flava & Slovakia & Nizkie Tatra Mts, 7 Aug 2011, R. Piwowarczyk (KTC) & Petasites kablikianus \\
\hline 9 & O. gracilis & Austria & Hundsheim, 14 Jun 2012, R. Piwowarczyk (KTC) & Anthyllis vulneraria \\
\hline 10 & O. hederae & Spain & Elx, palm garden, 28 Apr 2009, R. Piwowarczyk (KTC) & Hedera helix \\
\hline $11 \mathrm{a}$ & O. kochii & Poland & Pęczelice, 13 Jun 2010, R. Piwowarczyk (KTC) & Centaurea scabiosa \\
\hline $11 b$ & O. kochii & & Toporowice, 5 Jun 2008, R. Piwowarczyk (KTC) & Centaurea scabiosa \\
\hline 12 & O. lucorum & Poland & Warsaw, botanical garden, 10 July 2009, R. Piwowarczyk (KTC) & Berberis vulgaris \\
\hline $13 \mathrm{a}$ & O. lutea & Poland & Wesołówka, 17 Jun 2006, R. Piwowarczyk (KTC) & Medicago falcata \\
\hline $13 b$ & O. lutea & & Chomentówek, 6 Jun 2007, R. Piwowarczyk (KTC) & Medicago sativa \\
\hline $13 \mathrm{c}$ & O. lutea & & Młodzawy Duże, 2 Jun 2007, R. Piwowarczyk (KTC) & Medicago falcata \\
\hline 14 & O. mayeri & Poland & Pieniny Mts, Trzy Korony, 30 Jun 2009, R. Piwowarczyk (KTC) & Laserpitium latifolium \\
\hline 15 & O. minor & Poland & Żywiec, 19 Jun 2009, R. Piwowarczyk (KTC) & Trifolium repens \\
\hline $16 \mathrm{a}$ & O. pallidiflora & Poland & Bieszczady Mts, 14 Aug 2009, R. Piwowarczyk (KTC) & Carduus personata \\
\hline $16 b$ & O. pallidiflora & & Lubiatowo, 24 Jun 2009, R. Piwowarczyk (KTC) & Cirsium oleraceum \\
\hline $16 \mathrm{c}$ & O. pallidiflora & & Ciepłe, 5 Jul 2010, R. Piwowarczyk (KTC) & Cirsium arvense \\
\hline $16 \mathrm{~d}$ & O. pallidiflora & & Potok Mały, 29 Jun 2009, R. Piwowarczyk (KTC) & Cirsium arvense \\
\hline $17 \mathrm{a}$ & O. picridis & Poland & Pasturka, 25 Jun 2007, R. Piwowarczyk (KTC) & Picris hieracioides \\
\hline $17 b$ & O. picridis & & Machnów Stary, 9 Jun 2007, R. Piwowarczyk (KTC) & Picris hieracioides \\
\hline 18 & O. reticulata & Slovakia & Nizkie Tatra Mts, Puste, 5 Aug 2011, R. Piwowarczyk (KTC) & Carduus glaucus \\
\hline \multirow[t]{2}{*}{19} & O. teucrii & Austria & Hundsheim, 14 Jun 2012, R. Piwowarczyk (KTC) & Teисrium montanum \\
\hline & Phelipanche & & & \\
\hline $20 \mathrm{a}$ & P. arenaria & Poland & Zawiercie-Bzów, 11 Jun 2010, R. Piwowarczyk (KTC) & Artemisia campestris \\
\hline $20 \mathrm{~b}$ & P. arenaria & & Pasturka, 25 Jun 2007, R. Piwowarczyk (KTC) & Artemisia campestris \\
\hline 21 & P. bohemica & Poland & Zawiercie-Bzów, 11 Jun 2010, R. Piwowarczyk (KTC) & Artemisia campestris \\
\hline 22 & P. caesia & Ukraine & Askania Nova, 16 Jun 2011, R. Piwowarczyk (KTC) & Artemisia austriaca \\
\hline 23 & P. purpurea & Poland & Chrzanów, 18 Jun 2009, R. Piwowarczyk (KTC) & Achillea millefolium s.l. \\
\hline \multirow[t]{2}{*}{24} & P. ramosa & Poland & Zysławice, 7 Sep 2008, R. Piwowarczyk (KTC) & Nicotiana tabacum \\
\hline & Orobanchella & & & \\
\hline $25 \mathrm{a}$ & O. coerulescens & Poland & Dobrowoda, 19 Jun 2010, R. Piwowarczyk (KTC) & Artemisia campestris \\
\hline $25 \mathrm{~b}$ & O. coerulescens & & Pasturka, 25 Jun 2007, R. Piwowarczyk (KTC) & Artemisia campestris \\
\hline
\end{tabular}

total of the seven most informative quantitative and qualitative morphological characteristics was chosen for the analyses: width of exine (mean $\mu \mathrm{m})$; polar axis (mean $\mu \mathrm{m})$; equatorial diameter (mean $\mu \mathrm{m}$ ); polar/equatorial ratio; number of furrows on grain; sculpture of pollen grains (1-granules look like a ball of wool, 2-granules consisted of a few smaller round elements knitted together into a smooth surface, 3-microreticulate); arrangement of granules on the pollen surface: 1 -no areas without granules are present, 2-areas without granules are present, 
Table 2 Characters used in cluster analysis (comp. "Materials and methods")

\begin{tabular}{|c|c|c|c|c|c|c|c|}
\hline \multirow[t]{2}{*}{ Species } & \multicolumn{7}{|c|}{ Character } \\
\hline & $\begin{array}{l}\text { Polar } \\
\text { axis } \\
(\text { mean } \\
\mu \mathrm{m})\end{array}$ & $\begin{array}{l}\text { Equatorial } \\
\text { diameter } \\
(\mathrm{mean} \mu \mathrm{m})\end{array}$ & $\begin{array}{l}\text { Width of } \\
\text { exine } \\
(\text { mean } \\
\mu \mathrm{m})\end{array}$ & $\begin{array}{l}\text { Polar/ } \\
\text { equatorial } \\
\text { ratio }\end{array}$ & $\begin{array}{l}\text { Furrows } \\
\text { number } \\
\text { on grain }\end{array}$ & $\begin{array}{l}\text { Sculpture } \\
\text { of pollen } \\
\text { grains }\end{array}$ & $\begin{array}{l}\text { Arrangement } \\
\text { of granules }\end{array}$ \\
\hline $\begin{array}{l}\text { Orobanchella } \\
\text { coerulescens }\end{array}$ & 20.4 & 21.9 & 1.4 & 0.934 & 3 & 3 & 3 \\
\hline $\begin{array}{l}\text { Phelipanche } \\
\text { arenaria }\end{array}$ & 22.1 & 24.5 & 1.4 & 0.903 & 3 & 3 & 3 \\
\hline P. bohemica & 22.9 & 24.2 & 1.7 & 0.944 & 3 & 3 & 3 \\
\hline P. caesia & 25.0 & 23.8 & 1.3 & 1.053 & 3 & 3 & 3 \\
\hline P. purpurea & 21.6 & 22.1 & 1.5 & 0.977 & 3 & 3 & 3 \\
\hline P. ramosa & 19.3 & 21.3 & 1.4 & 0.905 & 3 & 3 & 3 \\
\hline $\begin{array}{l}\text { Orobanche alba } \\
\text { subsp. alba }\end{array}$ & 22.6 & 19.8 & 0.9 & 1.142 & 0 & 1 & 2 \\
\hline $\begin{array}{l}\text { O. alba subsp. } \\
\text { major }\end{array}$ & 22.5 & 18.9 & 0.9 & 1.191 & 0 & 1 & 2 \\
\hline O. alsatica & 27.5 & 22.6 & 0.9 & 1.219 & 0 & 2 & 2 \\
\hline$O$. bartlingii & 26.3 & 22.4 & 0.8 & 1.174 & 0 & 2 & 2 \\
\hline $\begin{array}{l}O . \\
\quad \text { caryophyllacea }\end{array}$ & 25.0 & 21.7 & 1.1 & 1.152 & 0 & 2 & 2 \\
\hline O. crenata & 20.2 & 18.2 & 0.9 & 1.110 & 0 & 2 & 2 \\
\hline O. elatior & 26.2 & 22.9 & 1.1 & 1.144 & 0 & 2 & 2 \\
\hline O. flava & 27.5 & 23.7 & 1.1 & 1.163 & 0 & 2 & 1 \\
\hline O. gracilis & 23.6 & 20.3 & 0.9 & 1.165 & 0 & 2 & 2 \\
\hline O. hederae & 24.8 & 21.3 & 1.1 & 1.162 & 0 & 1 & 2 \\
\hline O. kochii & 25.1 & 22.2 & 1.1 & 1.130 & 0 & 2 & 2 \\
\hline O. lucorum & 27.4 & 23.7 & 1.0 & 1.157 & 0 & 2 & 1 \\
\hline O. lutea & 23.8 & 20.8 & 0.8 & 1.144 & 0 & 2 & 2 \\
\hline O. mayeri & 28.8 & 24.2 & 1.0 & 1.189 & 0 & 2 & 2 \\
\hline O. minor & 23.3 & 19.6 & 0.8 & 1.188 & 0 & 2 & 1 \\
\hline O. pallidiflora & 23.9 & 20.8 & 0.8 & 1.151 & 0 & 2 & 2 \\
\hline O. picridis & 23.9 & 20.0 & 0.9 & 1.195 & 0 & 2 & 2 \\
\hline O. reticulata & 27.0 & 23.2 & 0.9 & 1.165 & 0 & 2 & 2 \\
\hline O. teucrii & 26.3 & 22.6 & 0.8 & 1.162 & 0 & 2 & 2 \\
\hline
\end{tabular}

3-no granules are present (different type of pollen sculpture). The characteristics used are listed in Table 2. The mean value of the characteristics measured or scored from all samples of the taxon was analysed using cluster analysis to illustrate the general relationships and similarities between them. The analysis was performed in order to obtain results providing a general overview and to determine whether different morphological groups exist and are separated into distinct clusters. Similarity between samples was calculated on the basis of Gower's general similarity coefficient. The dendrogram was prepared using the UPGMA method. Subsequently, principal coordinate analysis (PCoA) was performed on the basis of all quantitative and qualitative features. The goal of PCoA was the positioning of objects (individuals) in a space of reduced dimensionality while preserving their distance relationships. Data analyses were performed using MVSP 3.1 (Kovach 1999).

\section{Results}

\section{LM and SEM study}

Both LM and SEM observations enabled the team to distinguish, among Orobanche and Phelipanche pollen, two main groups with distinctly different features regarding pollen shape and exine micromorphology.

Group 1 contains pollen grains in monads, suboblate ( $P$. arenaria), oblate spheroidal ( $P$. purpurea, $P$. bohemica, $P$. ramosa and Orobanche coerulescens) (according to $\mathrm{P} / \mathrm{E}$ 


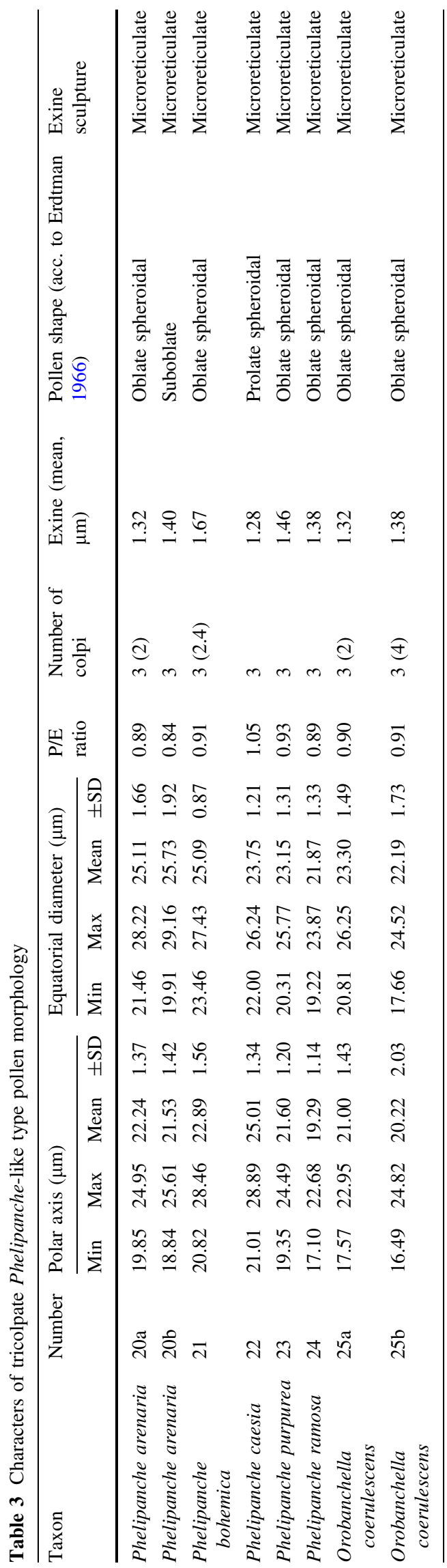

ratio) and prolate spheroidal ( $P$. caesia), and tricolpate (but some single grains with 2 or 4 colpi) forms. Some differences in colpi shape and distribution are visible (colpi were sometimes fused, wide at the equator and narrow near the poles) but these features appear in all members of group 1 (Tables 2, 3; Figs. 3, 5).

Group 2 contains pollen grains in monads, prolate spheroidal (O. kochii and O. crenata) to subprolate (other) and inaperturate forms, or with irregular colpi. The basic exine ornamentation type is granulate. Visible differences in the size of granules and their distribution are present between some species. Three types of granule surface were distinguished: (1) granules with almost smooth surfaces $(O$. caryophyllacea, O. flava, O. elatior, O. lucorum); (2) granules consisting of a few smaller round elements knitted together (O. caryophyllacea, O. picridis, O. minor, O. alba subsp. major, O. kochii, O. lutea, O. reticulata, O. teucrii, O. gracilis, O. crenata); and (3) granules consisting of elongated elements visible on granule surfaces (like balls of wool) (O. alba subsp. alba, O. hederae, O. kochii, O. flava) (Tables 2, 4; Figs. 1, 2, 4, 5).

According to differences in the size and distribution of granules, two main patterns of pollen surface ornamentation can be found: 1 -granules distributed over the whole pollen grain, but small areas without granules are present; the granules are of different sizes but always smaller than $1 \mu \mathrm{m}$; most granules are joined to others, but isolated granules are also present; 2-the surfaces are similar to those described above, but there are no areas without granules (Figs. 1, 2).

Statistical analysis

Cluster analysis (UPGMA) performed on the complete set of data (Table 2) resulted in the delimitation of two main subclusters. The first comprises a group of taxa with distinctly tricolpate pollen grains with reticulate surfaces, whereas the second comprises uncolpate grains with granulate surfaces (Figs. 3, 4, 5, 6). A similar pattern of results is shown by the ordination diagrams from the principal coordinate analysis (PCoA, not shown), also based on the complete quantitative and qualitative set of data. The first subcluster in UPGMA effectively separates the species $P$. ramosa, $P$. bohemica, $P$. arenaria, $P$. purpurea, $P$. caesia and Orobanchella coerulescens from all the rest of the specimens belonging to Orobanche placed in the second cluster. In the Phelipanche subcluster, all taxa are very similar in general habit, with tricolpate pollen grains. In cluster analysis, $P$. caesia differs slightly from the other members, with a higher polar/equatorial ratio and a thinner exine. However, pollen characteristics in this group of species are characterised by generally higher variance (Fig. 7). Although all the species located in the 
Table 4 Characters of inaperturate Orobanche-like type pollen morphology

\begin{tabular}{|c|c|c|c|c|c|c|c|c|c|c|c|c|c|}
\hline \multirow[t]{2}{*}{ Taxon } & \multirow[t]{2}{*}{ Number } & \multicolumn{4}{|c|}{ Polar axis $(\mu \mathrm{m})$} & \multicolumn{4}{|c|}{ Equatorial diameter $(\mu \mathrm{m})$} & \multirow{2}{*}{$\begin{array}{l}\mathrm{P} / \mathrm{E} \\
\text { ratio }\end{array}$} & \multirow{2}{*}{$\begin{array}{l}\text { Exine } \\
(\text { mean, } \\
\mu \mathrm{m})\end{array}$} & \multirow{2}{*}{$\begin{array}{l}\text { Pollen shape (acc. } \\
\text { to Erdtman 1966) }\end{array}$} & \multirow{2}{*}{$\begin{array}{l}\text { Exine } \\
\text { sculpture }\end{array}$} \\
\hline & & Min & Max & Mean & $\pm \mathrm{SD}$ & Min & $\operatorname{Max}$ & Mean & $\pm \mathrm{SD}$ & & & & \\
\hline $\begin{array}{l}\text { Orobanche alba } \\
\text { subsp. alba }\end{array}$ & 1 & 17.44 & 26.77 & 22.62 & 2.20 & 15.88 & 22.21 & 19.80 & 1.75 & 1.15 & 0.86 & Subprolate & Granulate \\
\hline $\begin{array}{l}\text { Orobanche alba } \\
\text { subsp. major }\end{array}$ & $2 \mathrm{a}$ & 18.72 & 29.79 & 23.10 & 2.86 & 16.24 & 23.86 & 19.11 & 1.92 & 1.21 & 0.89 & Subprolate & Granulate \\
\hline $\begin{array}{l}\text { Orobanche alba } \\
\text { subsp. major }\end{array}$ & $2 b$ & 17.94 & 25.52 & 21.84 & 1.77 & 14.11 & 21.33 & 18.63 & 1.92 & 1.18 & 0.84 & Subprolate & Granulate \\
\hline $\begin{array}{l}\text { Orobanche } \\
\text { alsatica }\end{array}$ & 3 & 21.25 & 33.45 & 27.50 & 3.12 & 15.46 & 29.08 & 22.57 & 2.86 & 1.23 & 0.87 & Subprolate & Granulate \\
\hline $\begin{array}{r}\text { Orobanche } \\
\text { bartlingii }\end{array}$ & 4 & 21.32 & 30.84 & 26.33 & 2.51 & 16.72 & 28.30 & 22.43 & 2.71 & 1.18 & 0.77 & Subprolate & Granulate \\
\hline $\begin{array}{l}\text { Orobanche } \\
\text { caryophyllacea }\end{array}$ & $5 \mathrm{a}$ & 21.20 & 28.06 & 24.52 & 1.44 & 18.36 & 23.65 & 21.29 & 1.30 & 1.15 & 1.20 & Subprolate & Granulate \\
\hline $\begin{array}{l}\text { Orobanche } \\
\text { caryophyllacea }\end{array}$ & $5 \mathrm{~b}$ & 19.68 & 30.21 & 25.44 & 2.55 & 17.24 & 27.79 & 22.10 & 2.65 & 1.16 & 1.04 & Subprolate & Granulate \\
\hline $\begin{array}{l}\text { Orobanche } \\
\text { caryophyllacea }\end{array}$ & $5 c$ & 19.83 & 28.00 & 23.17 & 1.99 & 15.22 & 24.67 & 19.50 & 2.03 & 1.19 & 1.09 & Subprolate & Granulate \\
\hline $\begin{array}{l}\text { Orobanche } \\
\text { crenata }\end{array}$ & 6 & 16.37 & 23.28 & 20.19 & 1.94 & 13.79 & 20.99 & 18.18 & 1.93 & 1.11 & 0.85 & Prolate spheroidal & Granulate \\
\hline $\begin{array}{l}\text { Orobanche } \\
\text { elatior }\end{array}$ & $7 \mathrm{a}$ & 21.52 & 30.83 & 25.91 & 2.44 & 17.71 & 27.52 & 22.67 & 2.48 & 1.15 & 1.12 & Subprolate & Granulate \\
\hline $\begin{array}{l}\text { Orobanche } \\
\text { elatior }\end{array}$ & $7 \mathrm{~b}$ & 20.30 & 34.47 & 26.44 & 3.75 & 17.52 & 32.19 & 23.07 & 3.78 & 1.15 & 1.11 & Subprolate & Granulate \\
\hline Orobanche flava & $8 \mathrm{a}$ & 18.90 & 30.42 & 24.88 & 2.59 & 15.78 & 25.06 & 21.40 & 2.33 & 1.17 & 1.09 & Subprolate & Granulate \\
\hline Orobanche flava & $8 b$ & 24.09 & 35.11 & 30.11 & 2.88 & 22.17 & 31.97 & 26.01 & 2.74 & 1.16 & 1.16 & Subprolate & Granulate \\
\hline $\begin{array}{l}\text { Orobanche } \\
\text { gracilis }\end{array}$ & 9 & 17.38 & 27.39 & 23.59 & 2.14 & 13.82 & 24.16 & 20.25 & 2.09 & 1.17 & 0.86 & Subprolate & Granulate \\
\hline $\begin{array}{l}\text { Orobanche } \\
\text { hederae }\end{array}$ & 10 & 21.59 & 30.67 & 24.77 & 2.40 & 17.21 & 25.30 & 21.31 & 2.02 & 1.17 & 1.11 & Subprolate & Granulate \\
\hline $\begin{array}{l}\text { Orobanche } \\
\text { kochii }\end{array}$ & $11 \mathrm{a}$ & 19.91 & 27.50 & 23.84 & 1.95 & 17.31 & 24.83 & 21.21 & 2.04 & 1.14 & 1.13 & Subprolate & Granulate \\
\hline $\begin{array}{l}\text { Orobanche } \\
\text { kochii }\end{array}$ & $11 \mathrm{~b}$ & 22.17 & 32.22 & 26.26 & 2.81 & 18.56 & 29.72 & 23.15 & 2.46 & 1.14 & 1.11 & Subprolate & Granulate \\
\hline $\begin{array}{l}\text { Orobanche } \\
\text { lucorum }\end{array}$ & 12 & 21.11 & 35.52 & 27.39 & 3.32 & 19.00 & 29.95 & 23.67 & 3.16 & 1.16 & 1.05 & Subprolate & Granulate \\
\hline Orobanche lutea & $13 \mathrm{a}$ & 18.36 & 26.78 & 22.26 & 2.36 & 15.54 & 22.33 & 19.31 & 1.71 & 1.15 & 0.75 & Subprolate & Granulate \\
\hline Orobanche lutea & $13 b$ & 20.71 & 29.98 & 25.43 & 2.25 & 15.67 & 25.70 & 22.48 & 2.29 & 1.15 & 0.77 & Subprolate & Granulate \\
\hline Orobanche lutea & $13 \mathrm{c}$ & 22.19 & 39.21 & 29.16 & 3.39 & 16.97 & 31.17 & 24.86 & 3.12 & 1.18 & 1.02 & Subprolate & Granulate \\
\hline $\begin{array}{l}\text { Orobanche } \\
\text { mayeri }\end{array}$ & 14 & 25.05 & 34.69 & 28.77 & 2.66 & 19.55 & 29.50 & 24.19 & 2.46 & 1.19 & 1.04 & Subprolate & Granulate \\
\hline $\begin{array}{l}\text { Orobanche } \\
\text { minor }\end{array}$ & 15 & 18.08 & 27.80 & 23.28 & 1.93 & 15.60 & 24.30 & 19.59 & 2.37 & 1.20 & 0.78 & Subprolate & Granulate \\
\hline $\begin{array}{l}\text { Orobanche } \\
\text { pallidiflora }\end{array}$ & $16 \mathrm{a}$ & 18.75 & 27.16 & 22.23 & 2.15 & 16.37 & 23.90 & 19.43 & 2.03 & 1.15 & 0.70 & Subprolate & Granulate \\
\hline $\begin{array}{l}\text { Orobanche } \\
\text { pallidiflora }\end{array}$ & $16 b$ & 19.95 & 30.96 & 26.11 & 2.50 & 17.61 & 27.19 & 23.08 & 2.14 & 1.14 & 0.84 & Subprolate & Granulate \\
\hline $\begin{array}{l}\text { Orobanche } \\
\text { pallidiflora }\end{array}$ & $16 \mathrm{c}$ & 19.52 & 31.36 & 24.08 & 2.39 & 16.85 & 25.60 & 21.07 & 2.15 & 1.16 & 0.84 & Subprolate & Granulate \\
\hline $\begin{array}{l}\text { Orobanche } \\
\text { pallidiflora }\end{array}$ & $16 \mathrm{~d}$ & 18.03 & 28.42 & 23.02 & 3.10 & 14.71 & 24.19 & 19.55 & 2.49 & 1.18 & 0.70 & Subprolate & Granulate \\
\hline $\begin{array}{l}\text { Orobanche } \\
\text { picridis }\end{array}$ & $17 \mathrm{a}$ & 18.59 & 33.38 & 22.80 & 3.06 & 15.12 & 23.49 & 19.50 & 2.27 & 1.17 & 0.87 & Subprolate & Granulate \\
\hline
\end{tabular}


Table 4 continued

\begin{tabular}{|c|c|c|c|c|c|c|c|c|c|c|c|c|c|}
\hline \multirow[t]{2}{*}{ Taxon } & \multirow[t]{2}{*}{ Number } & \multicolumn{4}{|c|}{ Polar axis $(\mu \mathrm{m})$} & \multicolumn{4}{|c|}{ Equatorial diameter $(\mu \mathrm{m})$} & \multirow{2}{*}{$\begin{array}{l}\mathrm{P} / \mathrm{E} \\
\text { ratio }\end{array}$} & \multirow{2}{*}{$\begin{array}{l}\text { Exine } \\
(\text { mean, } \\
\mu \mathrm{m})\end{array}$} & \multirow{2}{*}{$\begin{array}{l}\text { Pollen shape (acc. } \\
\text { to Erdtman 1966) }\end{array}$} & \multirow{2}{*}{$\begin{array}{l}\text { Exine } \\
\text { sculpture }\end{array}$} \\
\hline & & Min & Max & Mean & $\pm \mathrm{SD}$ & Min & Max & Mean & $\pm \mathrm{SD}$ & & & & \\
\hline $\begin{array}{c}\text { Orobanche } \\
\text { picridis }\end{array}$ & $17 b$ & 18.92 & 33.61 & 25.01 & 3.49 & 13.34 & 25.45 & 20.52 & 2.70 & 1.23 & 0.88 & Subprolate & Granulate \\
\hline $\begin{array}{l}\text { Orobanche } \\
\text { reticulata }\end{array}$ & 18 & 19.56 & 31.04 & 27.00 & 2.63 & 19.35 & 27.83 & 23.17 & 1.84 & 1.19 & 0.85 & Subprolate & Granulate \\
\hline $\begin{array}{c}\text { Orobanche } \\
\text { teucrii }\end{array}$ & 19 & 22.67 & 31.29 & 26.31 & 1.86 & 16.09 & 25.75 & 22.63 & 2.12 & 1.17 & 0.83 & Subprolate & Granulate \\
\hline
\end{tabular}
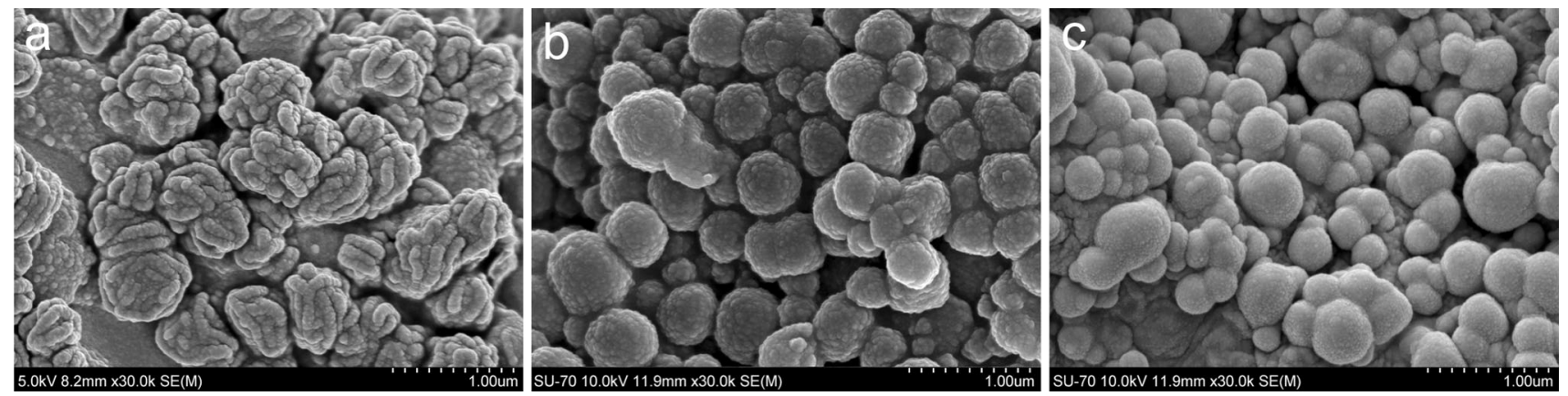

Fig. 1 Micromorphology of granules in selected species of Orobanche: a Orobanche hederae (granules like balls of wool), b O. reticulata (granules consisted of a few smaller round elements knitted together), c O. flava (granules glabrous or almost so)
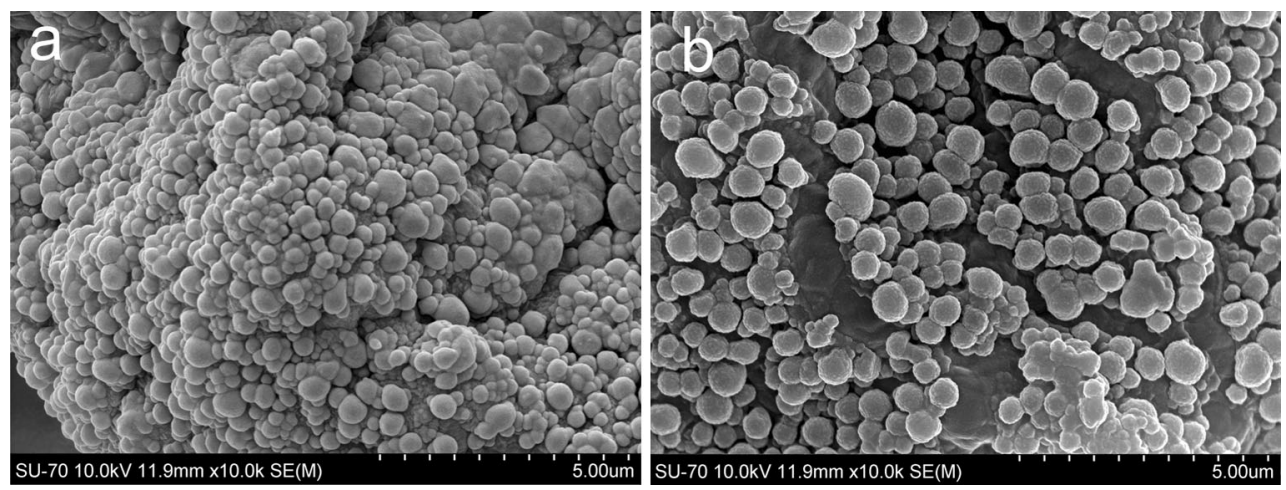

Fig. 2 Arrangement of granules on the pollen surface: a areas without granules not present (Orobanche flava), b bald areas without granules present $(O$. reticulata)

Orobanche subclade are very similar according to the general habit of pollen grains, two smaller subgroups of taxa can be distinguished. They differ mainly in the size of grains and width of exines (cf Fig. 8). In the first group, which comprises Orobanche alba s. lato, O. crenata, $O$. gracilis, O. hederae, O. lutea, O. minor, O. pallidiflora and $O$. picridis, the mean polar axis of the pollen grains is $<23.9$, the equatorial mean is $<20.8$ and the exine is generally narrower $(0.8-0.9 \mu \mathrm{m})$. In all the remaining taxa from the subclade, the mean polar axis of pollen grains varies from 23.3 to 28.8 , the equatorial mean is $21.3-24.2$ and the exine width is (0.8-) 0.9-1.1 $\mu \mathrm{m}$ (Table 2; Fig. 8).

In the Phelipanche group, a thinner exine has been noted in $P$. caesia, but at the same time, it has the highest value for equatorial and polar axis. The largest pollen grains in the Orobanche group were noted e.g. in O. elatior, O. flava or O. lucorum, the smallest in e.g. O. crenata and O. picridis. The thickest exines were recorded in $O$. caryophyllacea, O. elatior and $O$. flava, and the thinnest in O. lutea and $O$. bartlingii (Tables 2, 3, 4). 

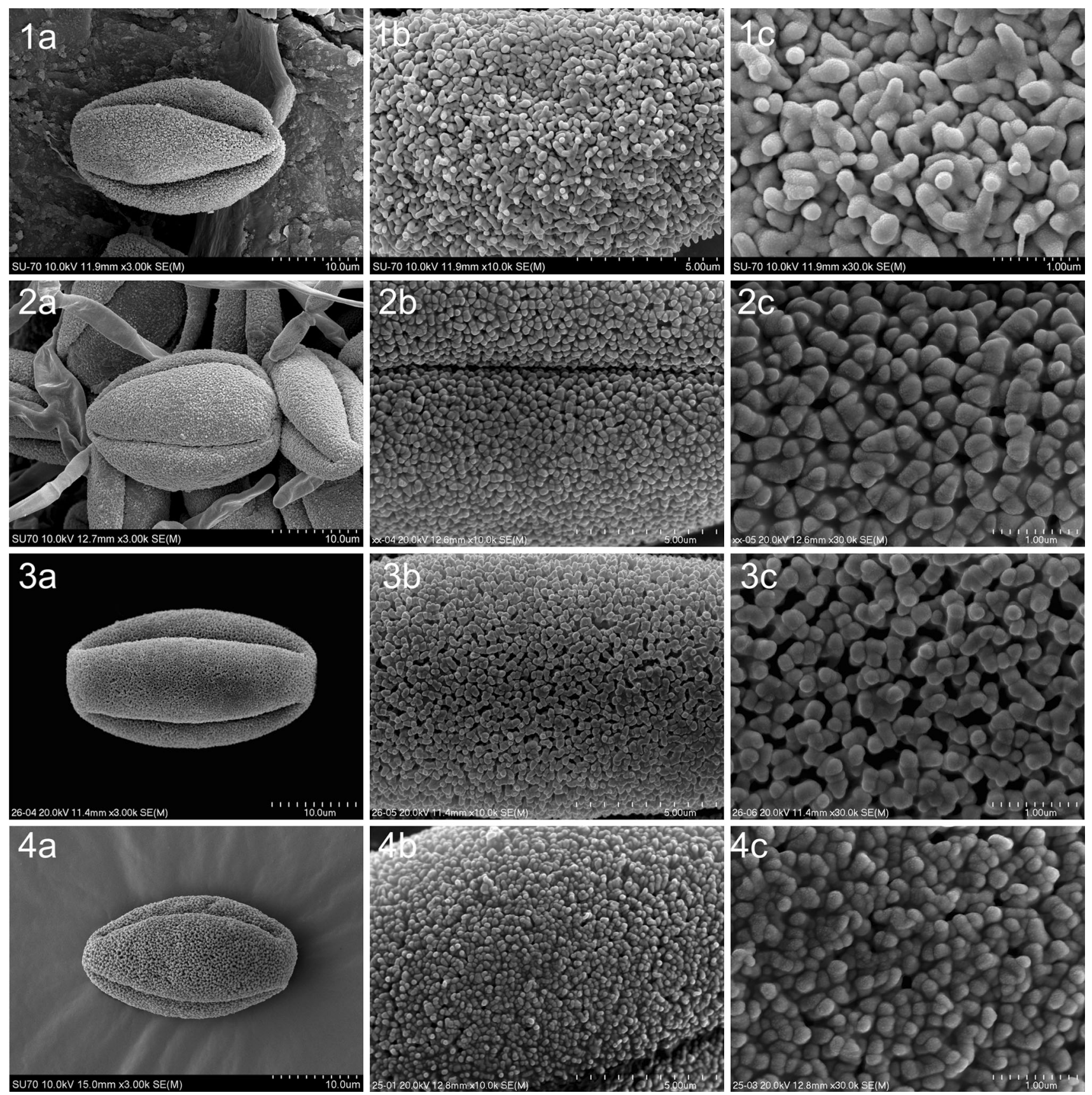

Fig. 3 Pollen grains and its micromorphology in: Orobanchella coerulescens (1), Phelipanche caesia (2), P. arenaria (3), P. ramosa (4); a general habit of pollen grain (magnification $\times 3,000$ ), $\mathbf{b}$, $\mathbf{c}$ microstructure of pollen grain (magnification $\times 10,000$ and $\times 30,000$ )

\section{Discussion}

Analysis of the pollen grains of Central European representatives of Orobanche s.l. showed that they are characterised by high variability, both inter- and intra-specific, as well as in relation to oligo- and polyphagous species parasitic on various hosts. In addition, some taxa may produce heteromorphic pollen grains (Zare et al. 2013), but this issue requires further study. Surely pollen characteristics, i.e. the number of apertures and the ornamentation of exines, cannot be overlooked, because they bear valuable information to help analyse evolutionary relationships and classifications within the Orobanchaceae family.

The characteristics of pollen are important criteria for distinguishing genera or sections, but are less important in distinguishing species. However, it is worth mentioning the subtle yet noticeable differences in the size and sculpture of pollen of species treated in different taxonomic units, i.e. species of the problematic complex $O$. alsatica s.l., namely $O$. alsatica, $O$. bartlingii and $O$. mayeri, all three of which 

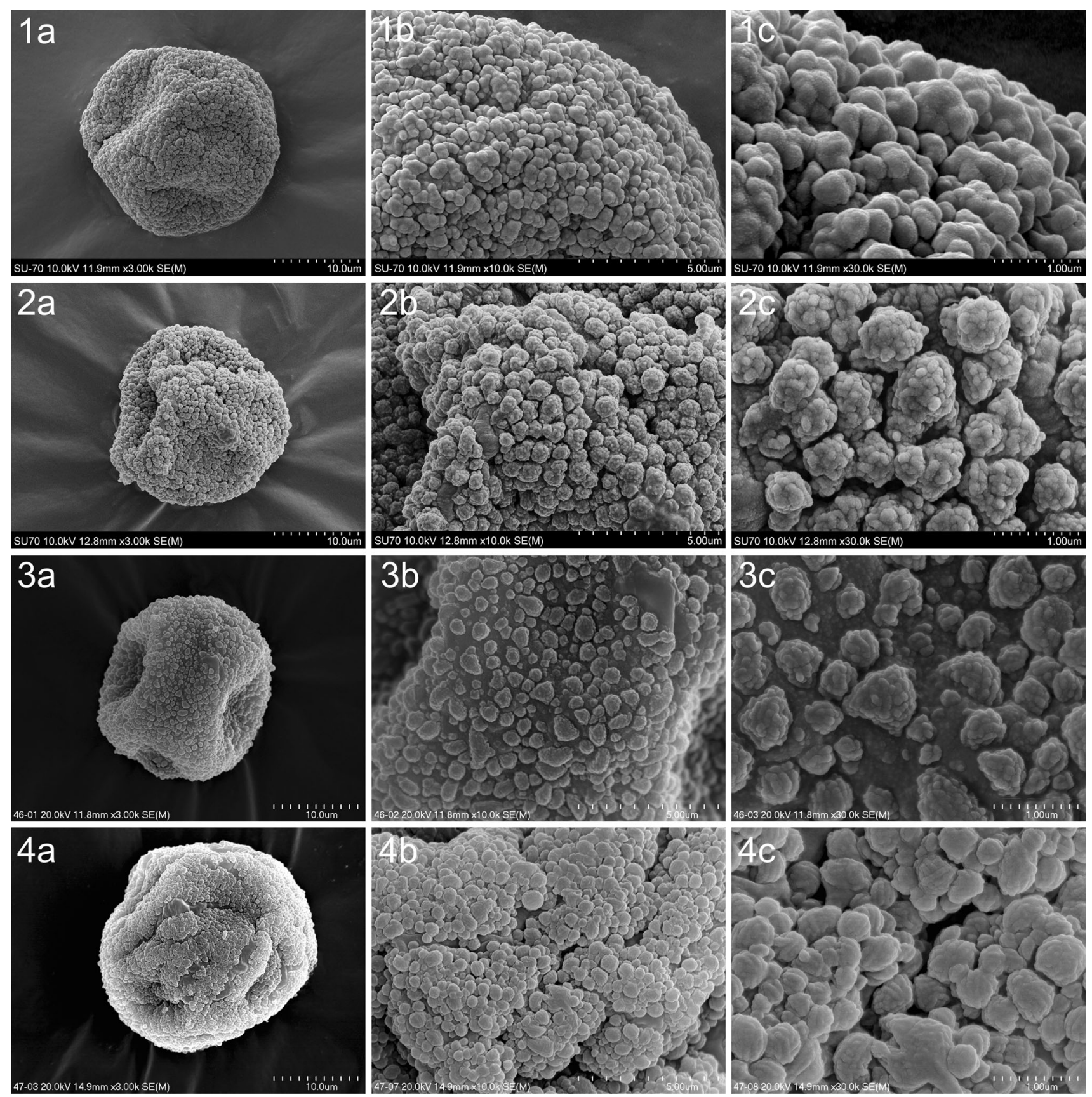

Fig. 4 Pollen grains and its micromorphology in: Orobanche caryophyllacea (1), O. alba subsp. alba (2), O. lutea (3), O. flava (4); a general habit of pollen grain (magnification $\times 3,000$ ), $\mathbf{b}$, $\mathbf{c}$ microstructure of pollen grain (magnification $\times 10,000$ and $\times 30,000$ )

are parasites of Apiaceae (Piwowarczyk 2011, 2012c; Piwowarczyk et al. 2014). In another example, O. pallidiflora, the species is treated differently in various studies: as a separate taxon, or in the rank of subspecies or variety within Orobanche reticulata (Beck von Mannagetta 1890, 1930; Zázvorka 2000; Pusch and Günther 2009). O. reticulata and $O$. pallidiflora differ in morphology, habitat and altitudinal ranges as well as host preferences (e.g. Kreutz 1995; Piwowarczyk et al. 2010). Our study showed that
O. pallidiflora has thinner exines and smaller equatorial and polar axes than $O$. reticulata, along with differences in sculpture. Orobanche bohemica as a separate species was first described by Čelakovský (1879). It has been assigned to different taxonomic ranks, e.g., that of a variety, by Beck von Mannagetta (1930) and Hayek (1914); as a subspecies of Phelipanche purpurea, by e.g. Zázvorka (2000) and Carlón et al. (2008); or as a separate species, by Holub and Zázvorka (1999), Pusch (2006), Pusch and Günther (2009), and 

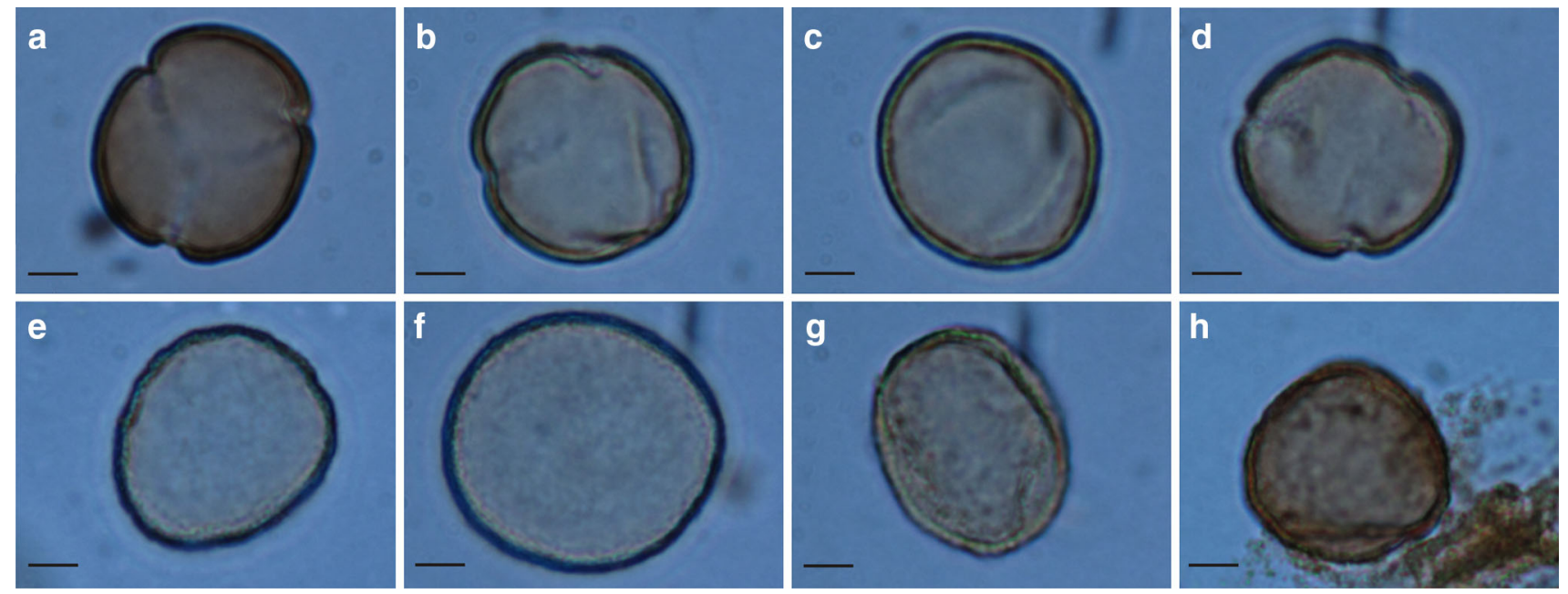

Fig. 5 Pollen grains of Orobanchella coerulescens $(\mathbf{a})$, Phelipanche caesia $(\mathbf{b})$, P. arenaria $(\mathbf{c})$, P. ramosa $(\mathbf{d})$, Orobanche caryophyllacea $(\mathbf{e})$, $O$. alba subsp. alba (f), O. lutea (g) and O. flava (h). Scale bar $5 \mu \mathrm{m}$

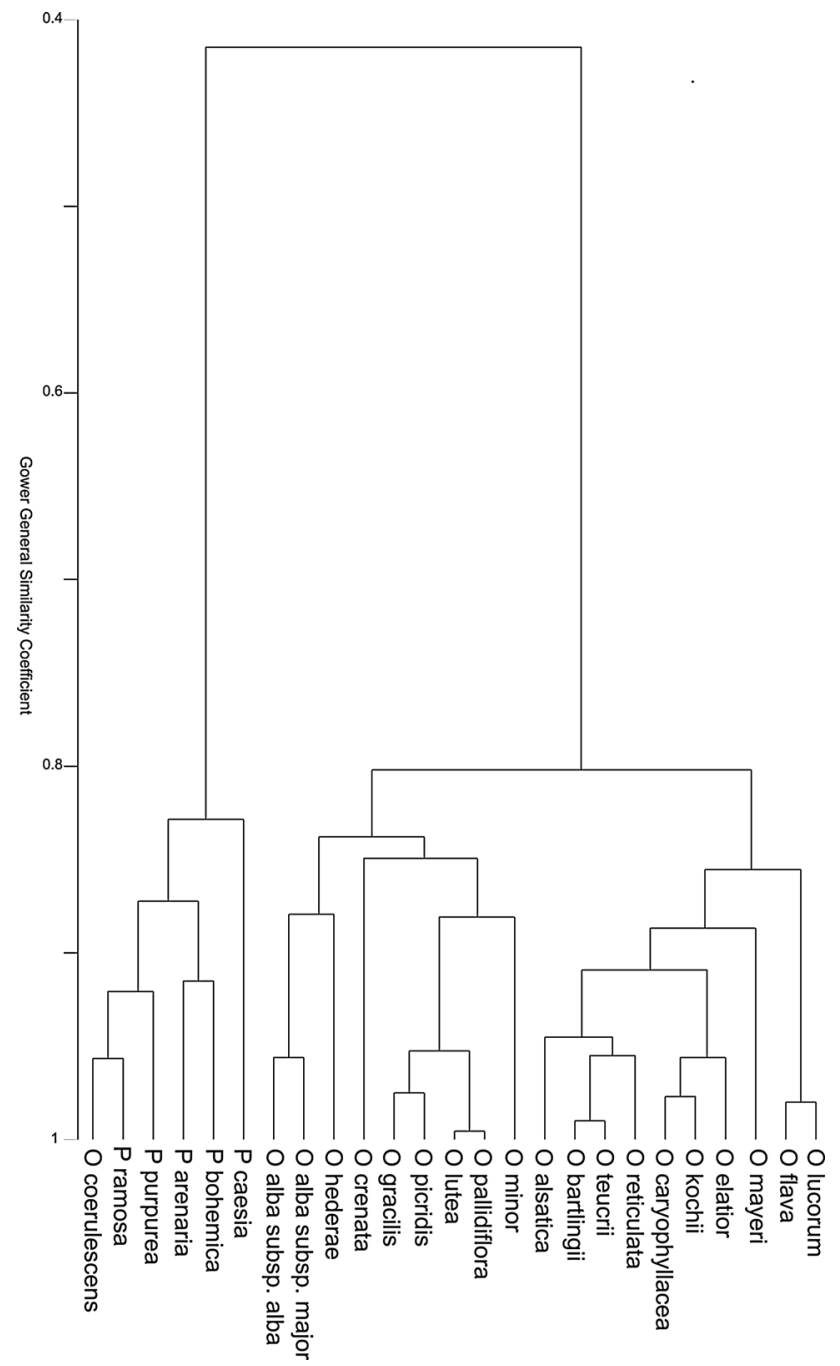

Fig. 6 Cluster analysis (UPGMA method of classification and Gower's general similarity coefficient) performed on seven quantitative and qualitative characters of pollen grains
Piwowarczyk (2012f, g). Palynological analysis also revealed auxiliary micromorphological differences: $P$. bohemica has a thicker exine and larger equatorial and polar axes than $P$. purpurea, along with differences in sculpture. A Central European species, parasitic mainly on Centaurea, considered until recently as $O$. elatior s.l. and now recognised as two distinct species, $O$. elatior and $O$. kochii (Zázvorka 2010), also demonstrates subtle differences in the size and level of sculpture of pollen grains (Tables 2, 3, 4).

Our study of pollen morphology showed various characteristics of Orobanche coerulescens. $O$. coerulescens has a Eurasian distribution. It occurs in the Far East, Japan, China, the Caucasus, Latvia, Ukraine and Romania. Very rare in Central Europe, it is known from Slovakia, the Czech Republic, Austria, Germany and Poland. As a typical steppe plant, it has relict features of post-glacial Artemisia steppes in the western part of its range. The species is recognised as extinct in the majority of its localities at the western limit of its distribution and its populations are very scarce in Central Europe. It is mainly parasitic on Artemisia campestris (Zázvorka 2000; Pusch and Günther 2009; Piwowarczyk 2012d). Traditionally, the species was included in the section Orobanche, grex Coerulescentes Beck (Beck von Mannagetta 1890), or, according to the new classification, in the section Inflatae (Beck) Tzvel., subsection Coerulescentes (Beck) Teryokhin (Teryokhin et al. 1993). This subsection contains about 10 species, poorly known and often lacking a very clear taxonomic position, of mainly steppe parasites involving the genus Artemisia. They are mostly endemic, occurring mainly in eastern Asia and Russia (Teryokhin et al. 1993; Piwowarczyk 2012d). We have shown that the pattern of pollen grains of $O$. coerulescens clearly belongs to a Phelipanche tricolpate type of pollen with microreticulate 

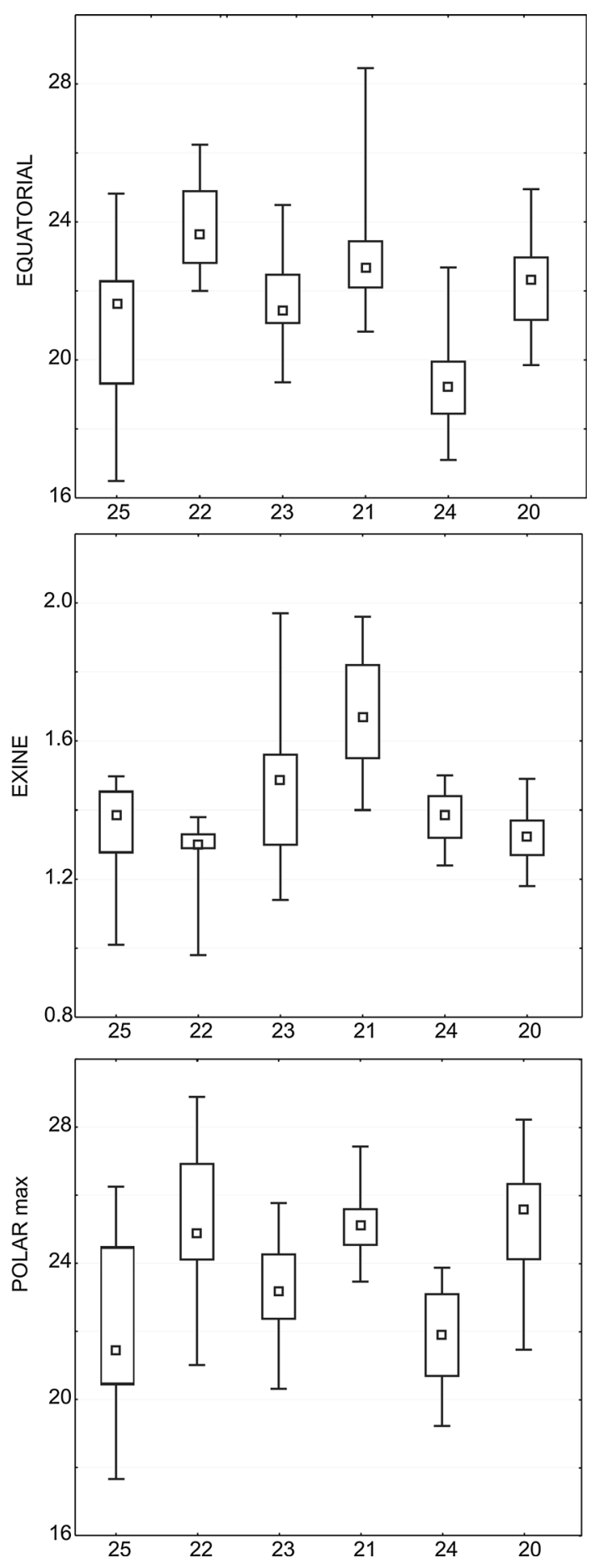

Fig. 7 Box and whisker plots of selected macromorphological characters of tricolpate Phelipanche-like pollen grains. Points indicate the mean value (open square), boxes represent 25 and $75 \%$ percentile, and range (whiskers) represents 1 and $99 \%$ percentile. Numbers indicated examined species (comp. Table 1)

sculpture (Figs. 3, 5). Previously, microreticulate sculpture of the exine was known only in Cistanche and Phelipanche (Zare et al. 2013). At the same time this contradicts the classification of the pollen of $O$. coerulescens by Zare et al.
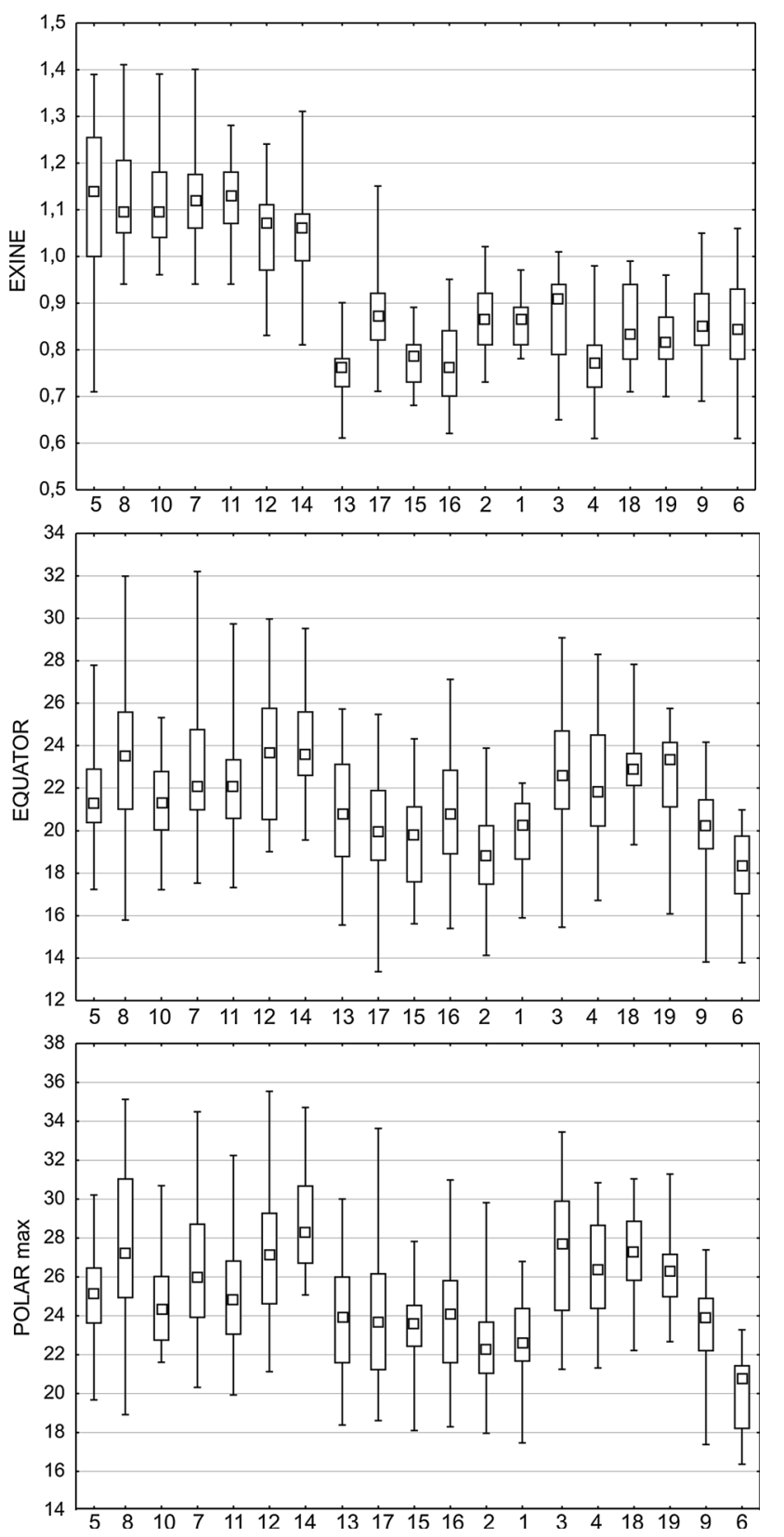

Fig. 8 Box and whisker plots of selected macromorphological characters of inaperturate Orobanche-like pollen grains. Points indicate the mean value (open square), boxes represent 25 and $75 \%$ percentile, and range (whiskers) represents 1 and $99 \%$ percentile. Numbers indicated examined species (comp. Table 1)

(2013) into the inaperturate type. Macromorphological characteristics indicate its intermediate position between Orobanche and Phelipanche. O. coerulescens is quite easy to distinguish from related species because of its characteristic thick stem, especially near the inflorescence, and numerous tiny, geniculately bent, pale blue flowers. The entire plant, the stem in particular, is very hairy and, when dry, looks as if covered with mould (Piwowarczyk and Przemyski 2009). Features that place it within Orobanche 
Table 5 A comparison of the main characters distinguishing Orobanche, Phelipanche, Boulardia and Orobanchella

\begin{tabular}{|c|c|c|c|c|}
\hline \multirow[t]{2}{*}{ Character } & \multicolumn{4}{|l|}{ Genus } \\
\hline & Orobanche & Phelipanche & Boulardia & Orobanchella \\
\hline Bracteoles & Absent & $\begin{array}{l}2 \text { bracteoles under or } \\
\text { attached the calyx }\end{array}$ & Absent & Absent \\
\hline Stem & Simple & Branched or simple & Simple & Simple \\
\hline Calyx & $\begin{array}{l}\text { Divided into } 2 \text { lateral } \\
\text { segments }\end{array}$ & $\begin{array}{l}\text { Cylindrical or } \\
\text { campanulate with } 4-5 \\
\text { teeth }\end{array}$ & $\begin{array}{l}\text { Divided into } 2 \text { lateral } \\
\text { segments }\end{array}$ & Divided into 2 lateral segments \\
\hline Fruit & $\begin{array}{l}\text { Style persists, lateral } \\
\text { opening }\end{array}$ & $\begin{array}{l}\text { Style falls off, top } \\
\text { opening }\end{array}$ & $\begin{array}{l}\text { Style persists, lateral } \\
\text { opening }\end{array}$ & Style persists, lateral opening \\
\hline Colour of flowers & Yellow, red, brown & Usually blue, violet & $\begin{array}{l}\text { Violet, purple, rarely } \\
\text { white-pink, yellow }\end{array}$ & Light-blue, blue-violet \\
\hline $\begin{array}{l}\text { Colour of stigma } \\
\text { and anthers }\end{array}$ & $\begin{array}{l}\text { Yellow, orange, purple, } \\
\text { brown }\end{array}$ & $\begin{array}{l}\text { Usually white, rare } \\
\text { yellow-white }\end{array}$ & $\begin{array}{l}\text { Usually white, rare } \\
\text { yellow-white }\end{array}$ & Usually white, rare yellow-white \\
\hline \multicolumn{5}{|l|}{ Type of pollen } \\
\hline Aperture & Inaperturate & Tricolpate & Inaperturate & Tricolpate \\
\hline $\begin{array}{l}\text { Sculpture of the } \\
\text { exine }\end{array}$ & Granulate & Microreticulate & Granulate & Microreticulate \\
\hline Type of seeds & $\begin{array}{l}\text { Outer tangential wall } \\
\text { pitted or rarely smooth }\end{array}$ & $\begin{array}{l}\text { Wall with fibrillar } \\
\text { ornamentation }\end{array}$ & $\begin{array}{l}\text { Wall with fibrillar } \\
\text { ornamentation }\end{array}$ & $\begin{array}{l}\text { Periclinal wall granulate rugged or } \\
\text { smooth, very rare weakly pitted }\end{array}$ \\
\hline Chromosomes & $n=19$ & $n=12$ & $n=38$ & $n=19$ \\
\hline
\end{tabular}

are: absence of bracteoles, calyx divided into 2 lateral segments, style persist, lateral opening, number of chromosomes $n=19$; however, it is close to Phelipanche by virtue of such features as: blue or violet flowers, white stigma and anthers, and the presence of tricolpate pollen with microreticulate sculpture (Table 5). In the work of Manen et al. (2004), Schneeweiss et al. (2004b), and Weiss-Schneeweiss et al. (2006), it is shown for the first time to be a member of the Eurasian lineage $O$. coerulescens. Phylogenetic relationships also show a degree of separation of $O$. coerulescens from the rest of the species of the section Orobanche and place it in an intermediate position between Orobanche, Boulardia and Phelipanche (Schneeweiss et al. 2004a; Piednoël et al. 2012).

Summarising the above, we proposed to transferred Orobanche coerulescens to a new genus Orobanchella. A comparison of the main characters distinguishing Orobanche, Phelipanche, Boulardia and Orobanchella is presented in Table 5.

\section{New genus and combination}

Orobanchella R. Piwowarczyk, M. Nobis \& J. Madeja gen. nov.

Type: Orobanchella caerulescens (Stephan in Willdenow) R. Piwowarczyk, M. Nobis \& J. Madeja

Orobanchella coerulescens (Stephan in Willdenow) R. Piwowarczyk, M. Nobis \& J. Madeja comb. nov.
Basionym: Orobanche coerulescens Stephan in Willdenow, Sp. Pl. 3(1): 349, 1800.

Type: "Habitat in Sibiria versus Mare Caspium". Willdenow, 1800 (p. 349). According to Novopokrovskij and Tzvelev, 1958 (p. 72), described from area in vicinity of lake Inder "iz raiona Inderskogo ozera" (W Kazakhstan) (type in LE).

Acknowledgments Research financed by the (Polish) Ministry of Science and Higher Education, grants no. NN303357733 (2007-2009) and NN303551939 (2010-2013) to R. Piwowarczyk.

Open Access This article is distributed under the terms of the Creative Commons Attribution License which permits any use, distribution, and reproduction in any medium, provided the original author(s) and the source are credited.

\section{References}

Abu Sbaih HA, Jury SL (1994) Seed micromorphology and taxonomy in Orobanche (Orobanchaceae). Fl Medit 4:41-48

Abu Sbaih HA, Keith-Lucas DM, Jury SL, Tubaileh AS (1994) Pollen morphology of genus Orobanche L. (Orobanchaceae). Bot J Linn Soc 116:305-313

Beck von Mannagetta G (1890) Monographie der Gattung Orobanche. Bibl Bot 19. Theodor Fischer, Cassel

Beck von Mannagetta G (1930) Orobanchaceae. In: Engler A (ed) Das Pflanzenreich. Regni Vegetabilis Conspectus. Wilhelm Engelmann, Leipzig, pp 1-348

Bennett JR, Mathews S (2006) Phylogeny of the parasitic plant family Orobanchaceae inferred from phytochrome A. Amer J Bot 93(7):1039-1051 
Carlón L, Gómez Casares G, Laínz M, Moreno Moral G, Sánchez Pedraja Ó, Schneeweiss GM (2008) Más, a propósito de algunas Phelipanche Pomel, Boulardia F. W. Schultz y Orobanche L. (Orobanchaceae) del oeste del Paleártico. Documentos Jard Bot Atlántico (Gijón) 6:1-128

Čelakovský L (1879) Ueber eine neue oder verkannte Orobanche. Österr Bot Zeitschr 29:361-364

Erdtman G (1966) Pollen morphology and plant taxonomy, angiosperms. Hafner Publishing Co, New York

Erdtman G (1969) Handbook of palynology. An introduction to study of pollen grains and spores. Munksgaard, Copenhagen

Faegri K, Iversen I (1989) Textbook of pollen analysis, 4th edn. In: Faegri K, Kaland PE, Krzywinski K (eds). Wiley, New York

Greuter W, Raab-Straube E (2009) Euro + Med Notulae, 4. Willdenowia 39:327-333

Halamski AT, Piwowarczyk R (2008) Graines d'Orobanches comme critere taxonomique-information sur les travaux en cours. Bull Mens Soc Linn Lyon 77(3-4):37-40

Hayek A (1914) Orobanchaceae. In: Hegi G (ed) Illustrierte Flora von Mitteleuropa, vol 6. München, pp 132-155

Hesse M, Halbritter H, Zetter R, Weber M, Buchner R, FroschRadivo A, Ulrich S (2009) Pollen terminology. An illustrated handbook. Springer Wien, New York

Holub J (1977) New names in Phanerogamae 6. Folia Geobot Phytotax 12:417-432

Holub J (1990) Some taxonomic and nomenclatural changes within Orobanche s. 1. (Orobanchaceae). Preslia 62:193-198

Holub J, Zázvorka J (1999) Phelipanche bohemica. In: Cerovsky J et al (eds) Cervena kniha ohrozenych a vzacnych druhu rostlin a zivocichu CR a SR, vol 5. Bratislava, p 279

Joel DM (2009a) Taxonomic and evolutionary justifications for considering Phelipanche as a separate genus. In: Ministry of Agriculture and Rural Affairs and Ege University (eds). Proceedings of the International parasitic plant society (IPPS), 10th World Congress of parasitic plants, 8-12 June 2009. Kusadasi, Turkey, pp 152

Joel DM (2009b) The new nomenclature of Orobanche and Phelipanche. Weed Res 49(Suppl. 1):6-7

Jones M (1991) Studies into the pollination of Orobanche species in the British Isles. Prog Orobanche Res Tubingen 1:6-17

Kovach WL (1999) MVSP - a multivariate statistical package for windows, ver. 3.1. Kovach Computing Services, Pentraeth

Kreutz CAJ (1995) Orobanche. The European broomrape species. Central and northern Europe. Natuurhistorisch Genootschap, Limburg

Manen JF, Habashi C, Jeanmonod D, Park JM, Schneeweiss GM (2004) Phylogeny and intraspecific variability of holoparasitic Orobanche (Orobanchaceae) inferred from plastid rbcL sequences. Mol Phylogen Evol 33(2):482-500

Minkin PJ, Eshbaugh WH (1989) Pollen morphology of the Orobanchaceae and Rhinanthoid Scrophulariaceae. Grana 28:1-18

Nobis M, Nowak A, Nobis A, Paszko B, Piwowarczyk R, Nowak S, Plášek V (2014) Contribution to the flora of Asian and European countries: new national and regional vascular plants records. Acta Bot Gal 160(1):81-89

Novopokrovskij IV, Tzvelev NN (1958) Orobanchaceae. In: Shishkin BK (ed) Flora Unionis Republicarum Socialisticarum Sovieticarum (Flora URSS), 23:19-117. Institutum Botanicum nomine V. L. Komarovii Academiae Scientiarum URSS, Mosqua, Leningrad, pp 685-687

Ollerton J, Stott A, Allnutt E, Shove S, Taylor C, Lamborn E (2007) Pollination niche overlap between a parasitic plant and its host. Oecologia 151(3):473-485

Park J, Manen J, Schneeweiss G (2007a) Horizontal gene transfer of a plastid gene in the non-photosynthetic flowering plants
Orobanche and Phelipanche (Orobanchaceae). Mol Phylogen Evol 43(3):974-985

Park J, Schneeweiss G, Weiss-Schneeweiss H (2007b) Diversity and evolution of Ty1-copia and Ty3-gypsy retroelements in the nonphotosynthetic flowering plants Orobanche and Phelipanche (Orobanchaceae). Gene 387(1-2):75-86

Piednoël M, Aberer AJ, Schneeweiss GM, Macas J, Novak P, Gundlach H, Temsch EM, Renner SS (2012) Next-generation sequencing reveals the impact of repetitive DNA across phylogenetically closely related genomes of Orobanchaceae. Mol Biol Evol 29(11):3601-3611. doi:10.1093/molbev/mss168

Piwowarczyk R (2011) Orobanche mayeri (Suess. \& Ronniger) Bertsch \& F. Bertsch-the new species to Poland. Acta Soc Bot Pol 80(3):179-183

Piwowarczyk R (2012a) The genus Orobanche L. (Orobanchaceae) in the Wyżyna Małopolska upland (S Poland): distribution, habitat, host preferences and taxonomic problems. Biodivers Res Conserv 26:3-22

Piwowarczyk R (2012b) Orobanche alba subsp. alba and subsp. major (Orobanchaceae) in Poland: current distribution, taxonomy, plant communities, hosts, and seed micromorphology. Biodivers Res Conserv 26:23-38

Piwowarczyk R (2012c) Revised distribution and plant communities of Orobanche alsatica and notes on the Orobanchaceae series Alsaticae in Poland. Biodivers Res Conserv 26:39-51

Piwowarczyk R (2012d) Revised distribution and phytosociological data of Orobanche coerulescens Stephan in Willd. (Orobanchaceae): Poland in relation to Central Europe. Biodivers Res Conserv 26:61-72

Piwowarczyk R (2012e) A revision of distribution and the ecological description of Orobanche picridis (Orobanchaceae) at the NE limit of its geographical range from Poland and Ukraine. Acta Agrobot 65(1):91-106

Piwowarczyk R (2012f) Orobanche bohemica Čelak. (Orobanchaceae) at the eastern limit of its geographical range: new data on its distribution in Poland. Biodivers Res Conserv 26:53-59

Piwowarczyk R (2012g) Orobanche purpurea (Orobanchaceae) in Poland: current distribution, taxonomy, plant communities, and preferred hosts. Biodivers Res Conserv 26:73-81

Piwowarczyk R (2012h) A revision of distribution and historical analysis of preferred hosts of Orobanche ramosa (Orobanchaceae) in Poland. Acta Agrobot 65(1):53-62

Piwowarczyk R (2013) Seed productivity in relation to other schoot features for endangered parasitic plant Orobanche picridis F.W. Schultz (Orobanchaceae). Polish J Ecol 61(1):55-64

Piwowarczyk R, Jankowska-Blaszczuk M (2014) Intra-specific diversity of seed productivity and morphological features in parasitic species Orobanche bartlingii Griseb. (Orobanchaceae). Polish J Ecol (in press)

Piwowarczyk R, Przemyski A (2009) New locality of Orobanche coerulescens Stephan ex Willd. (Orobanchaceae) at the NW limit of its geographical range. Acta Soc Bot Pol 78(4):291-295

Piwowarczyk R, Przemyski A (2010) The distribution and habitat preferences of the declining species Orobanche arenaria (Orobanchaceae) at the northern limit of its geographical range. Acta Soc Bot Pol 79(1):43-50

Piwowarczyk R, Nobis M, Przemyski A (2009) Orobanche bartlingii Griseb. (Orobanchaceae) in Poland: taxonomical position, distribution and habitat requirements. Biodivers Res Conserv 13:3-8

Piwowarczyk R, Chmielewski P, Gierczyk B, Piwowarski B, Stachyra P (2010) Orobanche pallidiflora Wimm. \& Grab. in Poland: distribution, habitat and host preferences. Acta Soc Bot Pol 79(3):197-205

Piwowarczyk R, Chmielewski P, Cwener A (2011) The distribution and habitat requirements of the genus Orobanche L. (Orobanchaceae) in SE Poland. Acta Soc Bot Pol 80(1):37-48 
Piwowarczyk R, Halamski AT, Durska E (2014) Seed and pollen morphology in the Orobanche alsatica complex (Orobanchaceae) and its taxonomic significance. Austral Syst Bot (in press)

Plaza L, Fernández I, Juan R, Pastor J, Pujadas A (2004) Micromorphological studies on seeds of Orobanche species from the Iberian Peninsula and the Balearic Islands, and their systematic significance. Ann Bot (Oxford) 94:167-178

Polo JM (1987) Orobanchaceae. In: Valdes B, Dicz MJ, Fernandez I (eds) Atlas Polinico de Andalucia Occidental. Inst. De Desarollo Regional, \#43. de la Universidad de Sevilla, Sevilla

Pujadas Salvà AJ (2007) Novedades taxonómicas y nomenclaturalers en el género Orobanche L. (Orobanchaceae). Acta Bot Malacitana $32: 1-3$

Punt W, Hoen PP, Blackmore S, Nilsson S, Le Thomas A (2007) Glossary of pollen and spore terminology. Rev Palaeobot Palyn 143:1-81

Pusch J (2006) Die Böhmische Sommerwurz (Orobanche bohemica Čelak.)—Ein Beitrag zur Abgrenzung. Verbreitung und Gefährdung dieses zentraleuropäischen Endemiten Veröffentlichungen Naturkundemuseum Erfurt 25:127-148

Pusch J, Günther KF (2009) Orobanchaceae (Sommerwurzgewächse). In: Hegi G (ed) Illustrierte Flora von Mitteleuropa Bd. 6/1A, Lieferung 1. Weissdorn, Jena, pp 1-99

Rao TS (1963) Pollen morphology of two species of Orobanchaceae. Curr Sci 32:557-558

Schneeweiss GM (2001) Relationships within Orobanche sect. Trionychon: insights from its sequences markers. In: Fer A, Thalouarn P, Joel DM, Musselman LJ, Parker C, Verkleij JAC (eds) Proceeding of the 7th International Parasitic Weed Symposium. Nantes, France, pp 49-52

Schneeweiss GM (2007) Correlated evolution of life history and host range in the nonphotosynthetic parasitic flowering plants Orobanche and Phelipanche (Orobanchaceae). J Evol Biol 20(2):471-478

Schneeweiss GM, Colwell A, Park JM, Jang CG, Stuessy TF (2004a) Phylogeny of holoparasitic Orobanche (Orobanchaceae) inferred from nuclear ITS sequences. Mol Phylogen Evol 30(2):465-478
Schneeweiss GM, Palomeque T, Colwell A, Weiss-Schneeweiss H (2004b) Chromosome numbers and karyotype evolution of holoparasitic Orobanche (Orobanchaceae) and related genera. Amer J Bot 91(13):439-448

Shahi Shavvon R, Saeidi Mehrvarz S (2010) Pollen and seed morphology of the genus Cistanche (Orobanchaceae) in Iran. Biologia (Bratislava) 65(4):615-620

Teryokhin ES (1997) Weed Broomrapes-systematics, ontogenesis, biology, evolution. Aufstieg, Germany

Teryokhin ES, Shibakina GV, Serafimovich NB, Kravtsova T (1993) Determinator of broomrapes of the USSR flora. Nauka, Leningrad

Tiagi B (1951) Studies in the family Orobanchaceae. III. A contribution to the embryology of Orobanche cernua Loeffl. and O. aegyptiaca Pers. Phytomorph 1:158-169

Uhlich H, Pusch J, Barthel KJ (1995) Die Sommerwurzarten Europa: Gattung Orobanche. Westarp-Wiss, Magdeburg

Velasco L, Goffman FG, Pujadas A (2000) Fatty acids and tocochromanols in seeds of Orobanche. Phytochemistry 54:295-300

Weiss-Schneeweiss H, Greilhuber J, Schneeweiss GM (2006) Genome size evolution in holoparasitic Orobanche (Orobanchaceae) and related genera. Amer J Bot 93(1):148-156

Willdenow CL (1800) Caroli a Linné Species Plantarum. Tomus 3. Berolini

Zare G, Dönmez AA (2013) Two new records of the genus Orobanche (Orobanchaceae) from Turkey. Turk J Bot 37:1-7

Zare G, Dönmez AA, Dönmez EO (2013) Pollen morphology and evolution in the genus Orobanche L. s.l. and its allied genera (Orobancheae/Orobanchaceae) in Turkey. Pl Syst Evol. doi:10. 1007/s00606-013-0919-2

Zázvorka J (1997) Orobanchaceae Vent. Zárazovité. In: Goliášová K (ed) Flóra Slovenska, vol 5(2). VEDA, Bratislava, pp 460-529

Zázvorka J (2000) Orobanchaceae-zarazovite. In: Slavik B (ed) Kvetena Česke Republiky 6, Academia Praha

Zázvorka J (2010) Orobanche kochii and O. elatior (Orobanchaceae) in central Europe. Acta Mus Morav Sci Biol (Brno) 95(2):77-119 